\title{
Role of microphytobenthos in recovery of functions in a shallow-water sediment system after hypoxic events
}

\author{
Fredrik Larson $^{1,2, *}$, Kristina Sundbäck ${ }^{1}$ \\ ${ }^{1}$ Department of Marine Ecology, University of Gothenburg, PO Box 461, Göteborg 405 30, Sweden \\ ${ }^{2}$ Present address: SERG-group, Gatty Marine Laboratory, University of St Andrews, East Sands, St Andrews, Fife KY16 8LB, \\ Scotland, UK
}

\begin{abstract}
Several studies in shallow-water sediments have followed the recovery from hypoxia on a macro- or meiobenthic level, but on the microbenthic level such studies are rare. Outdoor flow-through mesocosms were used to monitor the resilience of a microbenthic community and nutrient turnover after hypoxia in natural, previously undisturbed sediment. Variables included oxygen and nutrient fluxes, denitrification and biomass (chl a) of microphytobenthos (MPB). Results showed that the community recovered rapidly after hypoxia ( $<15 \%$ of oxygen saturation). In a $7 \mathrm{~d}$ experiment preceded by $2 \mathrm{~d}$ of hypoxia, the initially changed oxygen and nutrient fluxes remained affected only during the first days after hypoxia. In a $50 \mathrm{~d}$ experiment, starting with $17 \mathrm{~d}$ of hypoxia, only nitrate under dark conditions remained significantly different at the termination of the experiment after a recovery period of $4.5 \mathrm{wk}$. The microbenthic community, as well as the basal functions, of shallow-water illuminated sediments possess a high resilience, at least after single events with short periods of hypoxia. This resilience appears to be related to the high resistance of MPB (especially diatoms) to hypoxia, which implies a rapid restoration of the oxygenation of the sediment surface and the base of the food web, securing food supply for new colonising grazers. The recovery was faster for functions under light conditions, indicating that the functions related to microalgal activity are less sensitive to hypoxic events than are heterotrophic processes.
\end{abstract}

KEY WORDS: Resilience · Recovery · Hypoxia · Sediment · Microphytobenthos · Denitrification . Oxygen $\cdot$ Nutrient fluxes

Resale or republication not permitted without written consent of the publisher

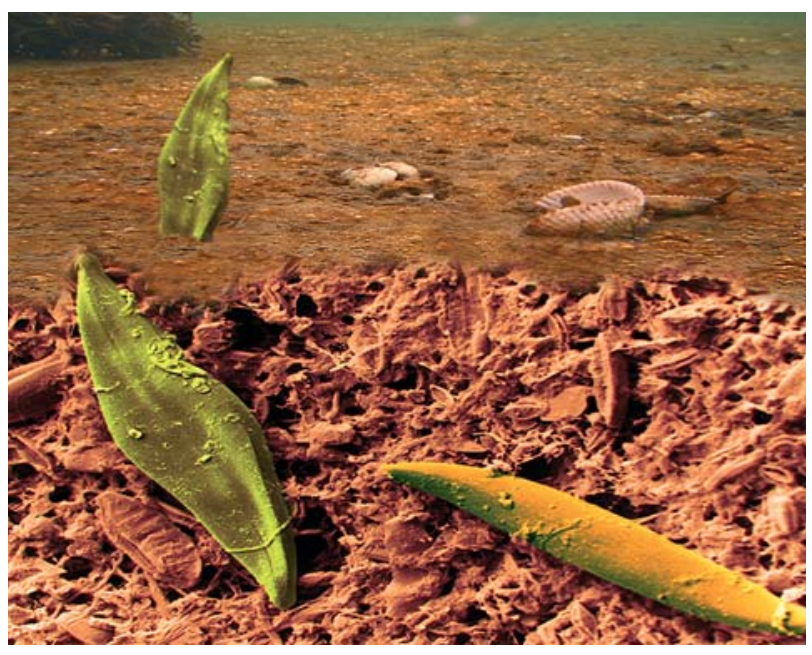

A photosynthetically active biofilm of diatoms, e.g. Gyrosigma spp., is important for the functional recovery of sediment systems after events of hypoxia

Image: Irvine Davidson (low temperature SEM), F. Larson (underwater photo, montage)

\section{INTRODUCTION}

Coastal ecosystems around the globe are subject to a wide range of disturbances caused by anthropogenic activities, e.g. eutrophication (Rosenberg et al. 1990, Nixon 1995, Howarth et al. 1996). Hypoxic and anoxic events are such frequently occurring disturbances. In shallow-water lagoons and embayments, benthic oxygen deficiency is often caused by the degradation of dense mats of ephemeral macroalgae (e.g. Ulva and Enteromorpha spp.), whose growth has been stimulated by increased nutrient levels (Viaroli et al. 1996, 
Pihl et al. 1999). Since coastal shallow-water areas are important nurseries and occasional habitats for economically important organisms, such as fish (e.g. Pihl \& Rosenberg 1982), and also function as buffer zones for nutrient transport between land and sea (Nielsen et al. 2004), we need to know more about how these productive habitats cope with, and recover from, anoxic and hypoxic events.

In shallow-water areas where the bottom substratum is soft, most important biogeochemical processes take place in the sediment, where dense microbenthic communities (microalgae, cyanobacteria, protozoa and bacteria) drive central ecosystem functions, such as primary production, decomposition and nutrient cycling (Paerl \& Pinckney 1996). In the present study we focus on the sensitivity and resilience of key system functions that are related to the activity of, above all, microphytobenthos (MPB). Understanding the resilience of MPB is crucial, since they constitute the only autochthonous source of primary production on sediments that lack macroscopic vegetation. Moreover, in shallow estuaries and lagoons their primary production often exceeds that of phytoplankton (Underwood \& Kromkamp 1999). MPB effectively also control sediment-water nutrient fluxes (for references see Sundbäck \& McGlathery 2005) and interfere with bacterial nitrogen turnover processes, such as nitrification and denitrification (Risgaard-Petersen 2003). Generally, microbial mats at the sediment surface tend to efficiently recycle nitrogen $(\mathrm{N})$, which results in its retention in the sediment (Paerl \& Pinckney 1996, Lomstein et al. 1998). Thus, microbenthic functions are crucial not only for the overall function of shallow-water sediments, but also for adjacent systems that depend on shallow areas for recruitment and food supply. Therefore, increased knowledge of the sensitivity and capacity of these communities to recover after perturbations, such as oxygen deficiency, is important for an effective management and sustainable use of coastal resources.

In seawater, hypoxia implies that the oxygen drops below $\sim 25 \%$ of water oxygen saturation $\left(2 \mathrm{ml} \mathrm{O}_{2} \mathrm{l}^{-1} \approx\right.$ $2.8 \mathrm{mg} \mathrm{O}_{2} \mathrm{l}^{-1}$ ) (Diaz \& Rosenberg 1995). Most organisms can tolerate short-term exposure to hypoxia, but exposure to concentrations below $2 \mathrm{mg} \mathrm{O}_{2} \mathrm{l}^{-1}\left(1.4 \mathrm{ml} \mathrm{O}_{2} \mathrm{l}^{-1} \approx\right.$ $18 \% \mathrm{O}_{2}$ saturation) will cause death of most biota in 1 to $4 \mathrm{~d}$ (Karim et al. 2002). Benthic diatoms, however, have shown remarkable resistance even to anoxic conditions (Admiraal 1984, Sundbäck \& Graneli 1988, McGlathery et al. 2001). For example, although anoxic sulphide-rich conditions decreased the total microalgal biomass by $50 \%$, diatom biomass remained unaltered (Sundbäck et al. 1990). This hints that benthic diatoms may play a vital role in the resilience of functions in microbenthic communities after hypoxic events.
Resilience has been extensively studied theoretically through modelling of ecosystems, often involving nutrient cycling and food web complexity. Models have, for example, predicted that resilience will increase with shorter food chains and higher turnover rates of limiting nutrients (DeAngelis et al. 1989). These predictions have also been empirically tested and verified by manipulation of a lake system (Carpenter et al. 1992). While the recovery rate of meio- and macrobenthos after hypoxia have been considered (e.g. Guerrini et al. 1998, Lu \& Wu 2000, Wetzel et al. 2002), little is known about the resilience of microbenthic communities after hypoxic events.

The aim of the present study was to assess the sensitivity and resilience of the functions of the microbenthic community of an illuminated shallow-water sediment system when subjected to hypoxia. There are several definitions of the term resilience (Grimm \& Wissel 1997). In the present study, we have defined resilience as the recovery rate (e.g. DeAngelis 1980, Carpenter et al. 1992, Austen et al. 2002), i.e. the time it takes for the post-hypoxic system to become indistinguishable from a reference system (cf. Underwood 1989). The emphasis was on processes controlled mainly by MPB and bacteria, i.e. primary production, sediment-water nutrient fluxes and nitrogen removal by denitrification. Our hypotheses were that (1) due to the high resistance of benthic diatoms, primary production is less sensitive and more resilient to hypoxia than are heterotrophic functions, and that (2) the resilience is dependent on the duration of the hypoxic event. The experimental approach was to expose intact sediments in mesocosms to short- (d) and longterm (wk) hypoxia $\left(<15 \% \quad \mathrm{O}_{2}\right.$ saturation) and then monitor post-hypoxic functions. To our knowledge, this is one of the first studies aimed at the resilience of the functions of a microbenthic community after hypoxia in marine illuminated sediments that also includes processes involved in nutrient cycling.

\section{MATERIALS AND METHODS}

General approach. Two experiments were made, 1 short-term ( $2 \mathrm{~d}$ of hypoxia) and 1 long-term (17 d of hypoxia). The initial manipulation with hypoxia was made on intact, undisturbed sediment in cylinders that were randomly placed in a flow-through mesocosm system. Prior to the hypoxic treatment, the cores were left in the system to acclimatize for $1 \mathrm{wk}$. Hypoxia was created through lowering of oxygen in the incoming water by $\mathrm{N}_{2}$-gas bubbling. An equal no. of cylinders used as controls were distributed with oxygenated water. The response and resilience of the microbenthic community after hypoxia was studied by sampling 
during $1 \mathrm{wk}$ after the short-term hypoxia and during $4.5 \mathrm{wk}$ after the long-term hypoxia. Functional variables included day- and nighttime measurements of oxygen (net primary production [NPP], and community respiration $[\mathrm{CR}])$, nutrient fluxes $\left(\mathrm{NH}_{4}{ }^{+}, \mathrm{NO}_{3}{ }^{-}+\mathrm{NO}_{2}{ }^{-}\right.$, $\left.\mathrm{PO}_{4}{ }^{3-}, \mathrm{Si}(\mathrm{OH})_{4}\right)$ and denitrification. Structural variables included the chlorophyll a $(\mathrm{chl} \mathrm{a})$ concentration of the sediment (as an estimate of MPB biomass) and qualitative composition of meiofauna. The abundance of macroscopic infauna was also assessed. Those aquaria that were sampled were discarded afterwards and a new set of aquaria was randomly chosen at the next sampling. Temperature, salinity and light intensity were registered regularly during the experiments. The shortterm experiment was carried out from the last day of June through the first week of July, with temperatures increasing from 20 to $25^{\circ} \mathrm{C}$ during the period. The long-term experiment started in the end of August and finished in October, with a more or less linear decrease of water temperature from 18 down to $8^{\circ} \mathrm{C}$.

Sediment collection. The sediment was collected from a boat using an Olausson box-corer $(30 \times 30 \mathrm{~cm})$ at a depth of 1.5 to $2 \mathrm{~m}$, in the eastern bay of Malö, SE Skagerrak (58 $12^{\prime} 05^{\prime \prime}$ N, $11^{\circ} 29^{\prime} 20^{\prime \prime}$ E) on the Swedish west coast (Fig. 1). This particular bay was chosen because it is an area with low risk of natural hypoxia. The selection of a bay without a history of hypoxic/

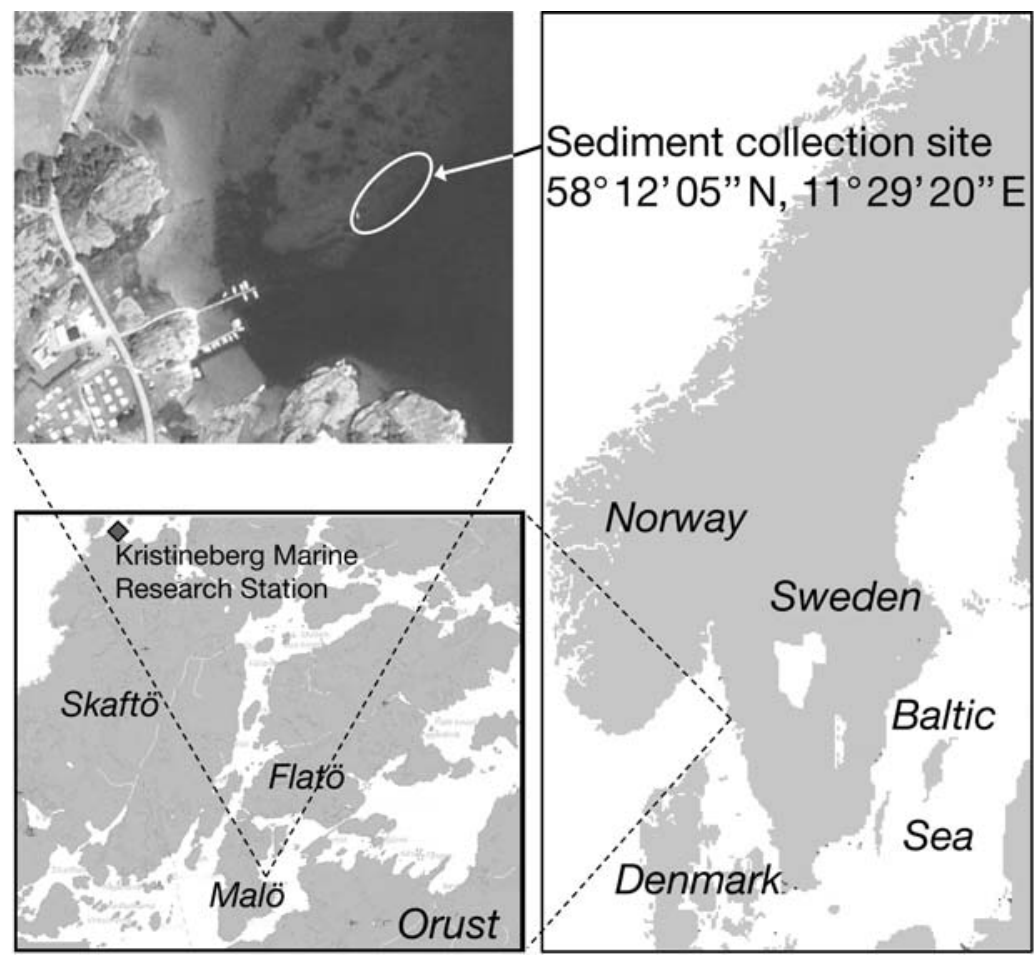

Fig. 1. Sediment collection site in the eastern bay of Malö on the Swedish west coast and the location of the Kristineberg Marine Research Station at Gullmar Fjord anoxic events was to ensure that the system was not pre-adapted and that it was totally fresh at the time of sampling. We wanted to fully control the hypoxic disturbance only through our manipulation.

The area is microtidal with a maximum tidal amplitude of $\sim 30 \mathrm{~cm}$, although water-level variation can be much higher due to weather conditions. When the sediment box-core was on deck, it was carefully handled so as not to disturb the sediment. A cylinder of black ABS plastic (co-polymer of acrylic nitrile-, butadieneand styrene monomers), with a height and inner diameter of $25 \mathrm{~cm}$, was lowered gently into the sediment until there was $\sim 10 \mathrm{~cm}$ left to the cylinder rim. A waterresistant plywood plate was inserted from the side to function as a bottom to the sediment in the cylinder. A total of 24 sediment cores were collected for the short-term and 48 for the long-term experiment. The sediment was silty with a surface porosity of 0.89 .

Experimental setup. The experiment was run in a flow-through mesocosm system at Kristineberg Marine Research Station located beside the Gullmar Fjord (Fig. 1). The system was placed in a greenhouse from which the side windows had been removed. This allowed natural light, although most UV was excluded, and temperature conditions while protecting the system against precipitation. The cylinders were positioned randomly and supplied with unfiltered water (to allow for immigration of larvae and spores) from $1 \mathrm{~m}$ depth in the Gullmar Fjord (salinity 28 to 31). The incoming water was led to an elevated water cistern (300 l) from which it was transported to 2 elevated 'bubbling towers' (one was used for production of hypoxic water, see 'Hypoxic treatment' below). From the towers the water was transported in $10 \mathrm{~mm}$ tubing by gravity to 4 tubes $(300 \mathrm{~cm} \times 10 \mathrm{~cm})$ (Fig. 2), each with 12 outlets $(6 \mathrm{~mm})$ positioned above the replicate cylinders. The outlets led to inlets $(4 \mathrm{~mm})$ placed $5 \mathrm{~cm}$ from the upper rim of each experimental cylinder, giving a flow rate of $\sim 10 \mathrm{l} \mathrm{h}^{-1}$. The depth of the overlying water was $\sim 10 \mathrm{~cm}$, giving a total water volume of 51 per cylinder. Visible epifauna were removed during acclimatization $(7 \mathrm{~d})$ prior to hypoxic treatment. This was because of risk for uneven surface disturbance that was biased through the initial collection method and not a reflection of the natural distribution.

Hypoxic treatment. Hypoxia was produced by bubbling nitrogen gas through one of the elevated towers. 
Since the system was based on flow-through of fresh seawater, the risk of carbon deficiency due to this bubbling was determined as minor. Half the no. of cylinders (12 in the short-term and 24 in the long-term experiment) were randomly connected to the tubes with hypoxic water, while the other half, the control cylinders, were connected to tubes with oxygenated water (Fig. 2). The level of oxygen was checked daily in all cylinders during the hypoxia treatment using Winkler titration. The common oxygen level provided to the hypoxic cylinders was kept below $15 \%$ (11 to $15 \%$ ) of oxygen saturation, and this was maintained by adjusting the flow of nitrogen gas through the 'bubbling tower'. The hypoxic treatment proceeded for $2 \mathrm{~d}$ in the short-term and for $17 \mathrm{~d}$ in the long-term experiment.

Sampling and analyses. Samples were taken on 3 occasions after the $2 \mathrm{~d}$ hypoxia and on 6 occasions after the $17 \mathrm{~d}$ hypoxia. The first sampling was on the same day as the hypoxic treatment ended, after the hypoxic cylinders had been flushed with oxygenated water. Samples were taken on Days 1, 3 and 7 (Day 0 was before the hypoxic treatment) after the short-term hypoxia and on Days 1, 2, 4, 8, 15 and 33 after the longterm hypoxia.

Oxygen and nutrient fluxes: At each sampling, fluxes were measured in 6 cylinders in the short-term $(\mathrm{n}=3)$ and in 8 cylinders in the long-term experiment $(\mathrm{n}=4)$, by incubation under lid without water-flow. The overlying water was stirred by a teflon-coated magnetic stirring bar under the lid to avoid concentration gradients due to stagnant conditions. The stirring bar was turned by an external u-magnet driven by an electric motor. Samples for oxygen $(30 \mathrm{ml}$ glass

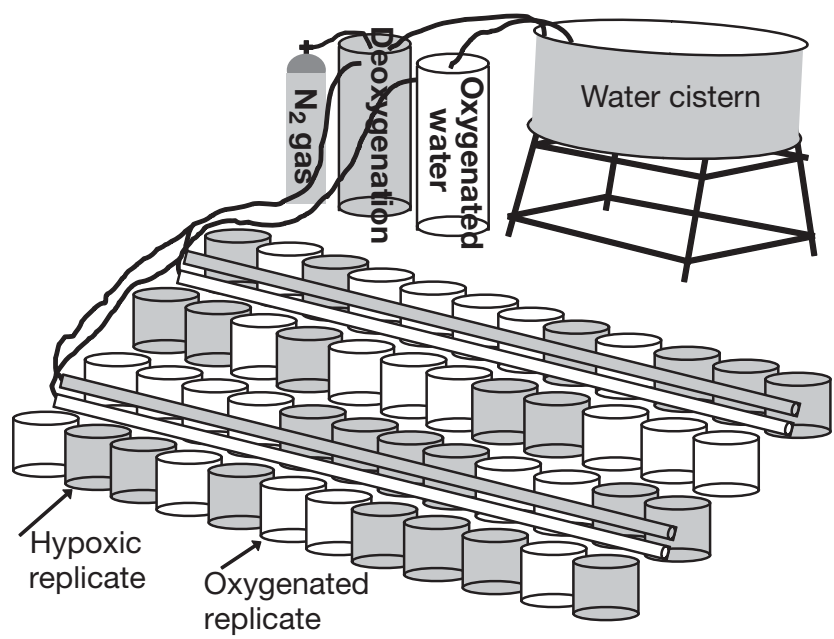

Fig. 2. Experimental setup used to create the hypoxic events in the sediment systems. Water to half of the replicate cylinders was lowered in oxygen level by nitrogen gas through a bubbling tower, and the level of oxygen was measured in all replicates. The level of hypoxia was regulated by tuning the flow syringe) and nutrient concentrations (20 $\mathrm{ml}$ disposable syringe) were taken at the beginning of the incubation. The time for the incubation was set so that the oxygen concentration would not change by more than $20 \%$, since larger changes can interfere with nutrient fluxes (Dalsgaard et al. 2000). The irradiance levels during the midday incubations varied between sampling days in the range of 400 to $1000 \mu \mathrm{mol} \mathrm{m}^{-2} \mathrm{~s}^{-1}$ in the air next to the experimental cylinders. The light was evenly distributed over the experimental setup. The incubation time averaged just over $1 \mathrm{~h}$ under light conditions (hereafter termed 'in light') and $\sim 2 \mathrm{~h}$ under dark conditions (hereafter termed 'in dark'). Light incubations were made between $\sim 12: 00$ and $\sim 13: 00 \mathrm{~h}$, and the dark incubations between $\sim 24: 00$ and $\sim 02: 00 \mathrm{~h}$. Oxygen samples were analyzed immediately after sampling using the Winkler technique (Strickland \& Parsons 1972). Nutrient samples were filtered (Sartorius ${ }^{\circledR} 0.45 \mu \mathrm{m}$ syringe filters) and frozen $\left(-80^{\circ} \mathrm{C}\right.$, stored $<3 \mathrm{mo}$ ) prior to analysis. $\mathrm{NH}_{4}{ }^{+}, \mathrm{NO}_{3}{ }^{-}+\mathrm{NO}_{2}{ }^{-}$(hereafter referred to as $\left.\mathrm{NO}_{3}{ }^{-}\right), \mathrm{PO}_{4}{ }^{3-}$ and $\mathrm{Si}(\mathrm{OH})_{4}$ were analyzed using wet-chemistry methods with a Bran-Luebbe TRAACS 2000 autoanalyzer (Bran-Luebbe).

Total denitrification: Light and dark incubations for denitrification were carried out after the long-term hypoxia using the isotope pairing technique (Nielsen 1992) by inserting small plexiglass cylinders (inner diameter $3.5 \mathrm{~cm}$, height $25 \mathrm{~cm}$ ) into the sediment. Denitrification incubations were made after the flux measurements. After taking initial nutrient samples from the denitrification cores, $1 \mathrm{ml}$ of $10 \mathrm{mM}^{15} \mathrm{NO}_{3}{ }^{-}$ (99.6 at.\%, Europe Scientific) was added to give a $\mathrm{NO}_{3}{ }^{-}$ concentration corresponding to $30 \%$ of the oxygen concentration (Dalsgaard et al. 2000). The label was allowed to diffuse into the sediment $(0.5 \mathrm{~h})$, after which new samples for nutrients were taken in order to get the actual start concentration of ${ }^{15} \mathrm{NO}_{3}{ }^{-}$. The cylinders were closed with tightly fitting plexiglass plugs and incubated for $\sim 2 \mathrm{~h}$. To terminate the incubation, $0.5 \mathrm{ml}$ $\left(1 \mathrm{~g} \mathrm{ml}^{-1}\right)$ zinc chloride $\left(\mathrm{ZnCl}_{2}\right)$ was added, and the sediment was slurred with the overlying water. Slurry samples were transferred into $12 \mathrm{ml}$ gas-tight vials, extra $\mathrm{ZnCl}_{2}(0.25 \mathrm{ml})$ was added and the vials were tightly closed and stored in a refrigerator $\left(8^{\circ} \mathrm{C},<2 \mathrm{wk}\right)$ until analysis. Produced ${ }^{29} \mathrm{~N}_{2}$ and ${ }^{30} \mathrm{~N}_{2}$ were analyzed using GC-MS at the National Environmental Research Institute. Calculations of total denitrification $\left(\mathrm{D}_{\text {tot }}\right)$ were made according to Dalsgaard et al. (2000).

Benthic microalgae: $\mathrm{Chl}$ a content of the sediment was used as a proxy for MPB biomass. Chl a samples were taken with a cut-off $2 \mathrm{ml}$ syringe from the top $3 \mathrm{~mm}$ of the sediment, pooling 4 sub-samples from each replicate cylinder. Chl a was extracted in $3 \mathrm{ml}$ $95 \%$ acetone, sonicated (10 min, with ice) and stored in a refrigerator $\left(8^{\circ} \mathrm{C}\right)$ for $24 \mathrm{~h}$. The samples were centri- 
fuged, the absorbance of the supernatant was analyzed using a spectrophotometer (Shimadzu UV 2401-PC) and chl a concentrations were calculated according to Lorenzen (1967).

Live and glutharaldehyde-preserved material was scanned in an epifluorescence microscope for dominating algal groups. No quantitative counts of MPB were made.

Fauna: Samples for meiofauna were taken with a cut-off $10 \mathrm{ml}$ syringe from the top $5 \mathrm{~mm}$ of the sediment, pooling 4 sub-samples from each cylinder. The meiofauna was extracted by decantation and collected on a $100 \mu \mathrm{m}$ sieve, and the composition was studied under a dissection microscope (no counts were made).

Macrofauna was collected after the sampling, by sieving (1 $\mathrm{mm}$ sieve) all the sediment from each cylinder, and then counted and classified to species or genera.

Porosity: Porosity of the sediment was determined by dividing the volume $(V)$ of water with the total sediment $V$. The total $V$ of sediment was given by a marked syringe at sampling, and the $V$ of water was determined by subtracting the sediment dry weight, after $24 \mathrm{~h}$ at $70^{\circ} \mathrm{C}$, from the wet weight.

Statistical analyses. Two-way analysis of variance (ANOVA), with Day and Treatment as fixed factors was used to test for significant effects on variables. When there was a significant interaction between factors, pair-wise comparisons of the means were made using the post-hoc SNK test. Occasionally, significance on a single day was tested 1-way ANOVA. This was done to increase resolution over periods without 2-way significance or with significant main treatment effects hiding patterns over time. We were aware of the higher risk for result errors, however, since it was community recovery that was being examined, we determined the risk less harmful because we wanted to find 'non-significance', therefore, the result we wanted was decreased by the occurring errors. As well as the general significance level $\alpha=0.05, \alpha=0.1$ is also shown since in ecological experiments, it is common to accept a higher level of probability for rejection.

Two-way permutational multivariate analysis of variance (PERMANOVA) (Anderson 2001, McArdle \& Anderson 2001) with Treatment and Day as fixed factors was used to analyze the integrated community function, i.e. the 'sum' of effects. The data set included denitrification, oxygen and nutrient fluxes in light and in dark. The raw data were not transformed but standardized through normalisation. The analysis was based on Euclidean distances and was run on data sets from the light and dark samplings, respectively. A total of 9999 unrestricted permutations of raw data were used in all tests. To test when the post-hypoxic cylinders were inseparable from the controls, a posteriori pair-wise com- parisons were done with the factor Treatment under each level of the factor Day. After the PERMANOVA, a test with permutational multivariate dispersion (PERMDISP) was run to find differences in within-group dispersion based on the sample distance to the group centroid. Principal coordinate analysis (PCO) was calculated and plotted. The multivariate analysis was run using the programs PERMANOVA v. 1.6, PERMDISP and PCO3 (M. J. Anderson pers. comm.).

\section{RESULTS}

\section{Sediment}

The sediment consisted of silty sand with a porosity of 0.89. In both experiments the sediment was initially covered by a brown diatom mat. In the short-term experiment the mat was thick and cohesive, remaining so throughout the $7 \mathrm{~d}$ experiment. Large sigmoid diatoms from the genera Gyrosigma and Pleurosigma, together with Cylindrotheca closterium and smaller naviculoid diatoms, were common. In the long-term experiment the diatom mat was thinner (cf. chl a content, Figs. 3a $\& 6 a)$ than in the first experiment and turned grey after the first days of hypoxia in the treated sediments. Cylidrotheca (3 size groups) and Navicula species (25 to $35 \mu \mathrm{m})$ dominated. The density of macrofauna was low $\left(\sim 300\right.$ ind $\left.\mathrm{m}^{-2}\right)$ and dominated by Nereid worms, Corophium spp. and smaller specimens of the bivalves Mya arenaria and Cerastoderma edule. The meiofauna was dominated in written order by nematodes, harpacticoid copepods and polychaete larvae.

\section{Short-term hypoxia}

Because the first sampling (Day 1) was immediately after the hypoxic treatment, the effects seen on Day 1 were considered to be direct effects caused by hypoxia, i.e. they reflected the sensitivity of the variables. Effects observed after Day 1 were considered to reflect resilience, i.e. the recovery process. On Day 1, effects of hypoxia were seen for 9 (4 in light and 5 in dark) out of 12 measured variables (Table 1). On the last day of the experiment (Day 7), only 3 effects remained, 1 in light and 2 in dark (Table 1). No visual changes of the sediment surface were observed, but dead fauna were found.

\section{Sensitivity}

On Day 1, no negative acute effect of the short-term hypoxia on the sediment chl a content was observed, but there was a slight increase of chl $a$ in the post- 
Table 1. Significant effects of $2 \mathrm{~d}$ (short-term) and $17 \mathrm{~d}$ (long-term) hypoxia analyzed using 2-way analysis of variance (ANOVA) and Student-Newman-Keuls (SNK) tests. Functional variables are showed separately for light and dark conditions. Denitrification was measured only after long-term hypoxia. Factors used were Day (D) and hypoxia Treatment $(\mathrm{T})$. $\mathrm{T}=\operatorname{single}$ main-factor effect of hypoxia; $\mathrm{D} \times \mathrm{T}=$ significant interaction between the 2 factors. Results from SNK or 1-way ANOVA are given as day no. in the column 'Significant on day(s)'. ${ }^{1 \mathrm{w}}$ indicates 1 -way ANOVA. Significances at $\mathrm{p}<0.05$ are shown in bold the rest are $\mathrm{p}<0.1$. NPP: net primary production; CR: community respiration

\begin{tabular}{|c|c|c|c|c|c|c|}
\hline & \multicolumn{3}{|c|}{ Short-term hypoxia } & \multicolumn{3}{|c|}{-Long-term hypoxia } \\
\hline & Factor & $\mathrm{p}$ & Significant on day(s) & Factor & $\mathrm{p}$ & Significant on day(s) \\
\hline \multicolumn{7}{|l|}{ Function in light } \\
\hline Oxygen flux (NPP) & $\mathbf{T}$ & 0.032 & $\mathbf{1}^{1 \mathrm{w}}$ & $\mathbf{T}$ & 0.001 & $1,2^{1 \mathrm{w}}$ \\
\hline Chl a-normalized NPP & & & $\mathbf{1}^{1 \mathrm{w}}$ & $\mathbf{D} \times \mathbf{T}$ & 0.036 & $1,2,8$ \\
\hline Ammonium flux & $\mathrm{D} \times \mathrm{T}$ & 0.059 & 1 & $\mathbf{D} \times \mathbf{T}$ & 0.0001 & 1,4 \\
\hline Nitrate flux & & & & & & $1^{1 \mathrm{w}}$ \\
\hline Denitrification & & & & $\mathbf{D} \times \mathbf{T}$ & 0.003 & $1,2,8,15$ \\
\hline Phosphate flux & $\mathrm{T}$ & 0.075 & $1,7^{1 \mathrm{w}}$ & & & $2^{1 \mathrm{w}}$ \\
\hline Silicate flux & $\mathbf{D} \times \mathbf{T}$ & 0.008 & 1,3 & & & $15^{1 \mathrm{w}}$ \\
\hline \multicolumn{7}{|l|}{ Function in dark } \\
\hline Oxygen (CR) & $\mathbf{D} \times \mathbf{T}$ & 0.002 & 1,7 & $\mathbf{D} \times \mathbf{T}$ & 0.0001 & $\mathbf{1}, 2,15$ \\
\hline Ammonium flux & $\mathbf{D} \times \mathbf{T}$ & 0.001 & 1,7 & $\mathrm{D} \times \mathrm{T}$ & 0.058 & 1,4 \\
\hline Nitrate flux & & & $1^{1 \mathrm{w}}$ & $\mathbf{T}$ & 0.0001 & $1,2,4,15,33^{1 \mathrm{w}}$ \\
\hline Denitrification & & & & $\mathbf{D} \times \mathbf{T}$ & 0.003 & $1,8,15$ \\
\hline Phosphate flux & $\mathbf{T}$ & 0.035 & $\mathbf{1}^{1 \mathrm{w}}$ & & & $1,2^{1 \mathrm{w}}$ \\
\hline Silicate flux & $\mathbf{D} \times \mathbf{T}$ & 0.006 & 1,3 & $\mathbf{T}$ & 0.04 & $\mathbf{1}^{1 \mathrm{w}}$ \\
\hline Chl a & & & $\mathbf{1}^{1 \mathrm{w}}$ & $\mathrm{T}$ & 0.08 & $2,8^{1 \mathrm{w}}$ \\
\hline
\end{tabular}

hypoxic treatment (Fig. 3a). However, at the same time, an effect of hypoxia on MPB was evident since significantly lower NPP (Fig. 4a), as well as chl anormalized production, was found ( $\mathrm{p}<0.05$ ) (Fig. 3b). In light, all nutrient fluxes were directed towards the sediment (Fig. 4). There was a lower $\mathrm{NH}_{4}$ uptake (Fig. 4c), while the nitrate flux was unaffected (Fig. 4e). The uptake of both phosphate and silicate was significantly lower in the post-hypoxic cylinders on Day 1 (Fig. 4g,i).

In the dark, CR in the post-hypoxic sediment was significantly higher on Day 1 ( $p<0.05$ ) (Fig. 4b). All dark nutrient fluxes were affected by hypoxia; uptake of ammonium ( $\mathrm{p}<0.05)$, nitrate $(\mathrm{p}<0.1)$ and phosphate $(\mathrm{p}<0.05)$ was lower (Fig. $4 \mathrm{~d}, \mathrm{f}, \mathrm{h})$ as was the release of silicate $(p<0.05)$ (Fig. $4 j)$. The multivariate analysis showed that the integrated system function was significantly different on Day 1 (Fig. 5).

\section{Resilience}

After Day 1, primary production in the post-hypoxic cylinders was no longer different from the control cylinders (Fig. 4a). On the other hand, effects in light were still evident for nutrient fluxes; silicate uptake was significantly higher on Day 3 (Fig. 4i), while phosphate uptake was lower on Day 7 ( $p<0.05$ ) (Fig. 4g). In the dark, 2 effects of hypoxia remained on the final day; CR was lower ( $p<0.1$ ) (Fig. 4 b) and the uptake of ammonium was higher ( $\mathrm{p}<0.05)$ (Fig. 4d). There was a silicate release on Day 3, when the controls showed an uptake ( $\mathrm{p}<0.05$ ) (Fig. 4j). Summing up the effects of hypoxia using the PERMANOVA showed

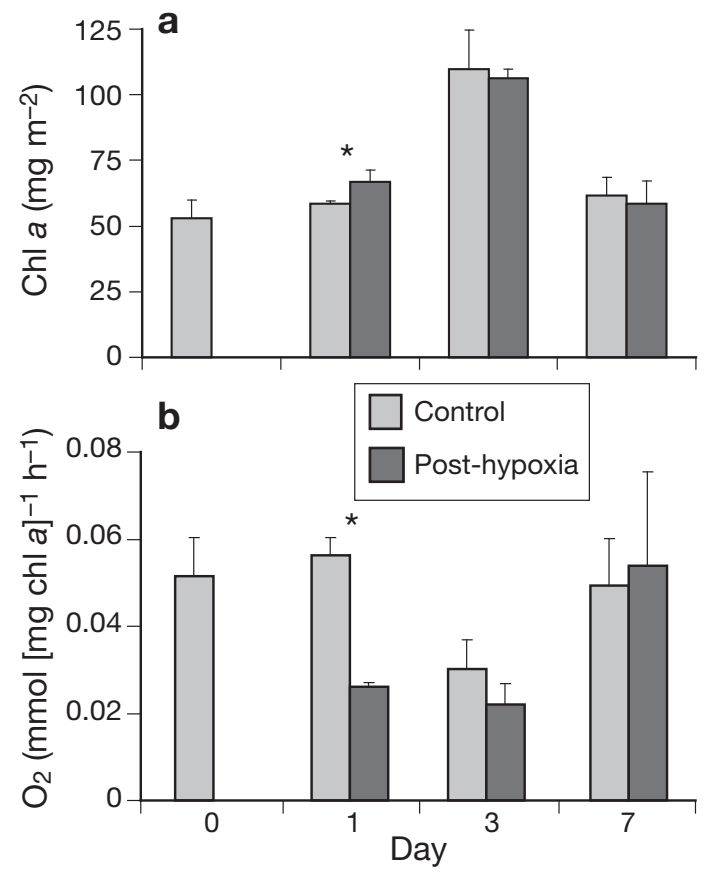

Fig. 3. Mean $(\mathrm{n}=3$ ) (a) chl a content of the sediment and (b) chl a-normalized primary production after 2 d hypoxia. Significant post-hypoxic effect (SNK or 1-way ANOVA) at ${ }^{*} \mathrm{p}<0.05$. Error bars: $\pm \mathrm{SE}$ 
Light

a

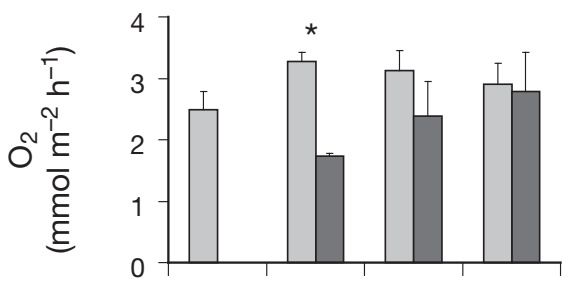

C
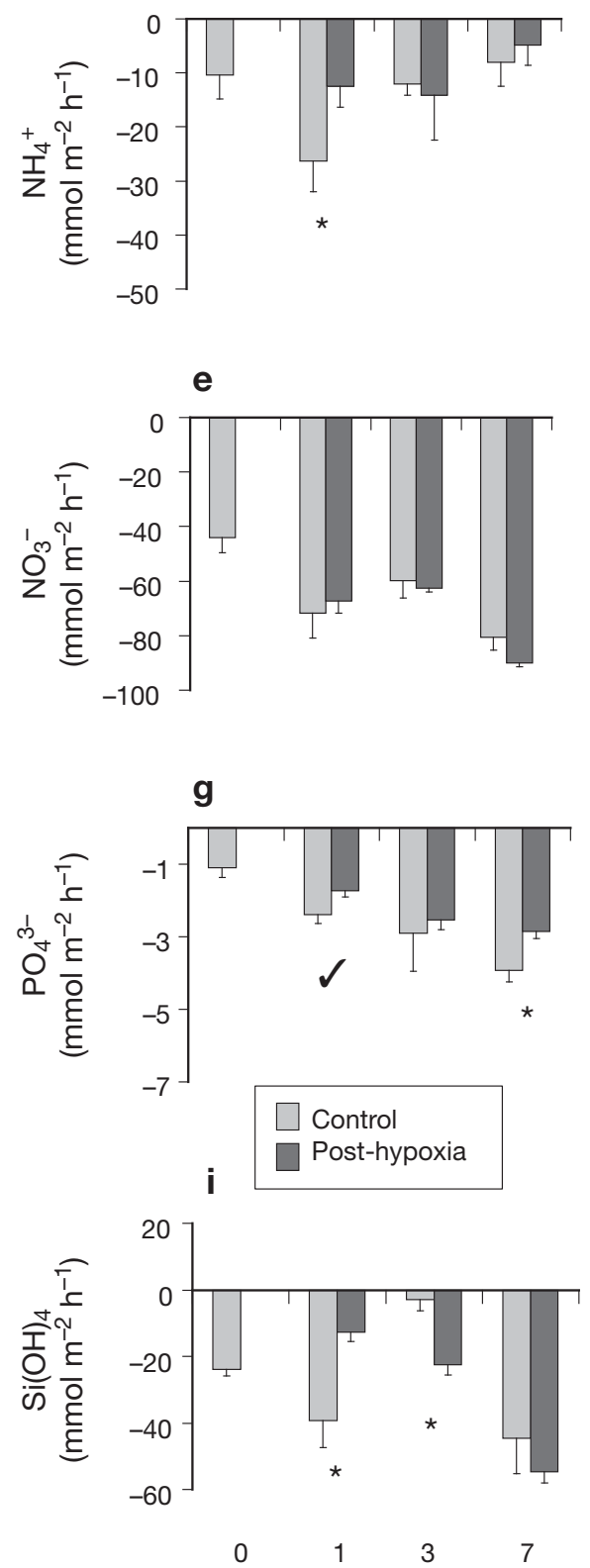

b

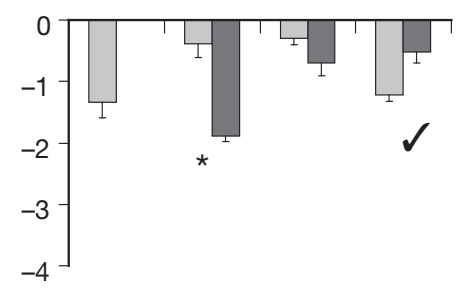

d
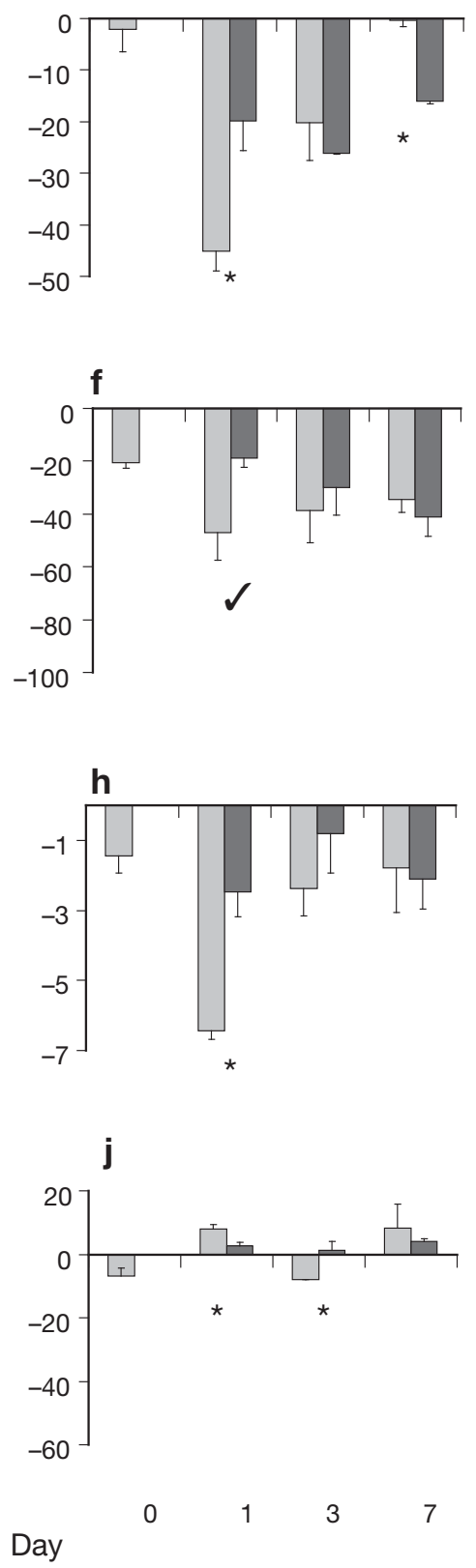

Fig. 4. Mean $(\mathrm{n}=3)$ oxygen and nutrient fluxes in light (daytime) and dark (nighttime) after 2 d hypoxia. (a,b) Oxygen, (c,d) ammonium, (e,f) nitrate, $(g, h)$ phosphate and $(i, j)$ silicate. Significant post-hypoxic effect (SNK or 1 -way ANOVA) at ${ }^{*} \mathrm{p}<0.05$ and $\boldsymbol{V} \mathrm{p}<0.1$. Error bars: $+\mathrm{SE}$ significant interactions between Treatment and Day in both light and dark (Table 2, upper part). Pair-wise comparisons revealed differences between posthypoxic and control treatments on Days 1 and 3 in light $(\mathrm{p}<0.05)$ and Days 1 and 7 in dark $(\mathrm{p}<0.05$ and $\mathrm{p}<0.1$ ) (Table 2, lower part). The analyses on dispersion (PERMDISP) revealed a significant interaction in the dark but with no single significances in the pair-wise test. In the dark, control treatments showed a trend towards larger dispersion than the posthypoxic cylinders. In light, it was found that the controls were more dispersed on Day 7 (p < 0.1) (Fig. 5).

\section{Long-term hypoxia}

As for the short-term experiment, effects on Day 1 were considered to reflect sensitivity, while later effects were considered to reflect resilience. On Day 1, 11 (5 in light and 6 in dark) out of 13 measured variables (light and dark) were affected by the previous $17 \mathrm{~d}$ hypoxia. On Day 33, only nitrate remained significantly different (Table 1). Visual changes were observed on the surface of the sediment in the hypoxic treatments after the first days of hypoxia exposure; the surface colour changed from brownish-yellow, typical of diatoms, to pale grey. Fauna were found dead on the sediment surface.

\section{Sensitivity}

Chl a was not affected on Day 1 (Fig. 6a). The chl a-normalized primary production (Fig. 6b), as well as the NPP (Fig. 7a), was significantly lower on Day 1 in the post-hypoxic sediment $(p<0.05)$. In light, ammonium and nitrate fluxes were lower $(\mathrm{p}<0.05)$ (Fig. 7c,e). Also, denitrification was lower after hypoxia $(p<0.05)$ (Fig. 7g). Phosphate and silica fluxes were not affected in light (Fig. 8a,c). In the dark, CR was significantly higher on Day 1 ( $\mathrm{p}<0.05$ ) (Fig. 7b). There was a lower uptake of ammonium, nitrate and phosphate and a release of silica in the post-hypoxic sediment $(p<0.05)$ 

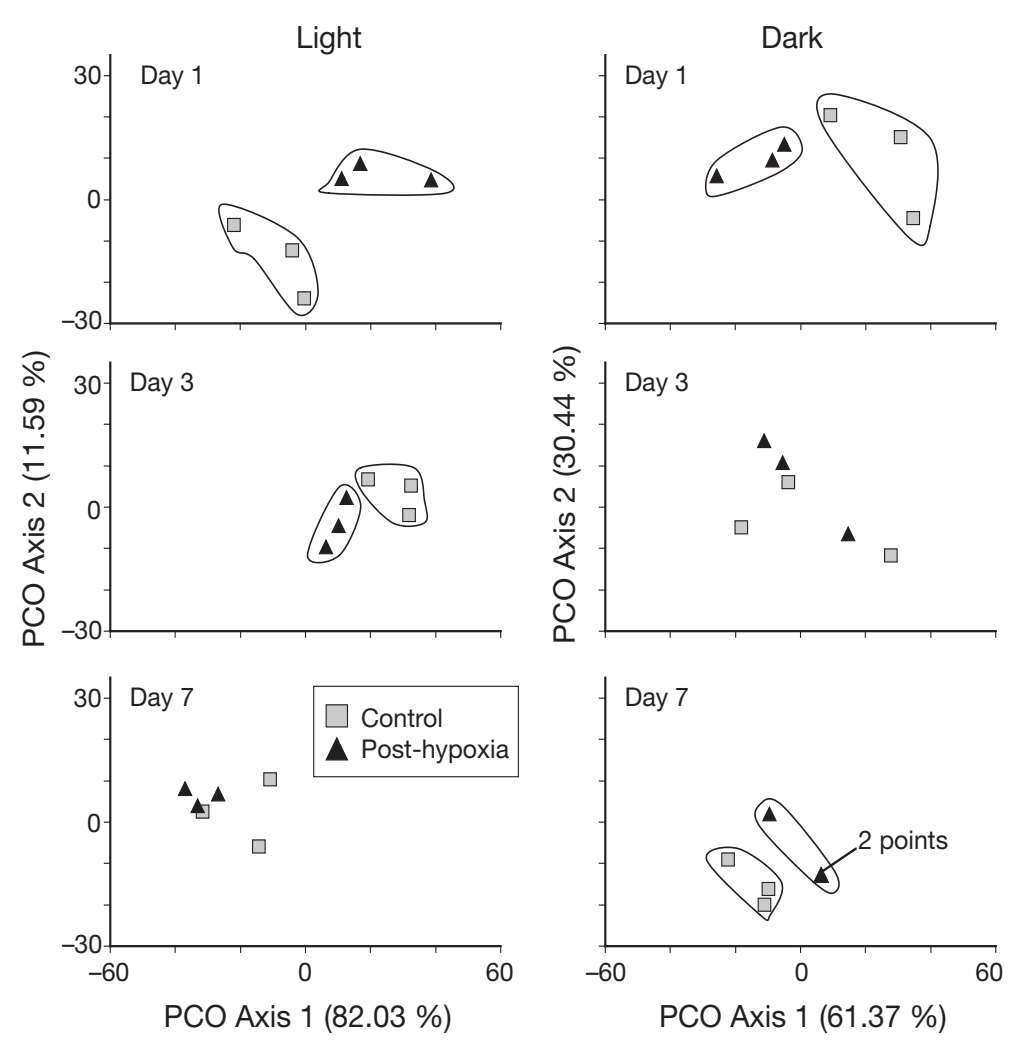

Fig. 5. Principal coordinate plot (PCO) of the treatments (control and post-hypoxia) based on analysis of the functional variables oxygen and nutrient fluxes $\left(\mathrm{NH}_{4}{ }^{+}, \mathrm{NO}_{3}{ }^{-}, \mathrm{PO}_{4}{ }^{-}, \mathrm{Si}(\mathrm{OH})_{4}\right)$ from the short-term experiment ( $2 \mathrm{~d}$ hypoxia). Axes show the percentages of explained variation. There is an initial separation of the treatment groups. The dispersion within groups is generally lower for the post-hypoxic cylinders. The separation under dark conditions on Day 7 is $p<0.1$. Significant groupings are encircled
(Figs. 7d,f,h \& 8d). Denitrification in the dark was lower on Day 1 ( $p<0.05)$. The PERMANOVA showed a significant separation of the groups on Day 1 after hypoxia. The dispersion was also significantly different in both light and dark (Table 3, Fig. 9).

\section{Resilience}

The chl a content of the sediment was significantly higher in the post-hypoxic cylinders on Days 2 and 8 (p < 0.1) (Fig. 6a). No effects remained for NPP after Day 2 (Fig. 7a), but the chl a-normalized production was lower on Days $2(p<0.1)$ and 8 ( $p<0.05$ ) (Fig. 6b). Among nutrient fluxes the effect remained until Day 4 for ammonium (Fig. 7c,d), until Day 8 for phosphate (Fig. 8b) and until Day 33, the end of the experiment, for nitrate (Fig. 7f). Denitrification remained affected until Day 15 (Fig. $7 g, h)$. The only nutrient flux that showed a consistent trend was nitrate in the dark, with a lower uptake (Fig. 7f). After Day 1 the PERMANOVA revealed an oscillating process of recovery (Table 3, Fig. 9). Significant separations were observed on Days 4 and 15 in light and Days 2 and 15 in dark. Also, the degree of within-group dispersion varied over time, with a higher dispersion seen for the post-hypoxic treatment.
Table 2. Effect of 2 d hypoxia on the integrated community function analyzed using 2-way permutational multivariate analysis of variance (PERMANOVA) (Anderson 2001) and permutational multivariate dispersion (PERMDISP) with $a$ posteriori pair-wise comparisons of Treatment $(\mathrm{T})$ under each level of Day (D). The variables included in the analysis are oxygen and nutrient fluxes (5 variables) analyzed for dark and light conditions, respectively. Significances at $p<0.05$ are bold, and $\mathrm{p}<0.1$ italic

\begin{tabular}{|lccccc|}
\hline \multicolumn{4}{c}{ PERMANOVA } & \multicolumn{2}{c|}{ PERMDISP } \\
& Factor & $F$ & $\mathrm{p}$ & $F$ & $\mathrm{p}$ \\
\hline Light & $\mathrm{D} \times \mathrm{T}$ & 7.9803 & $\mathbf{0 . 0 0 1 9}$ & 3.2939 & $\mathbf{0 . 0 3 3 8}$ \\
Dark & $\mathrm{D} \times \mathrm{T}$ & 4.2658 & $\mathbf{0 . 0 0 8 3}$ & 5.3267 & $\mathbf{0 . 0 1 6 2}$ \\
\multicolumn{7}{c}{ p posteriori pair-wise comparisons } & & \\
Light & & & $\mathbf{0 . 0 2 0 4}$ & & \\
Day 1 & & & $\mathbf{0 . 0 3 1 1}$ & & 0.4958 \\
Day 3 & & & 0.1522 & & 0.3028 \\
Day 7 & & & & & 0.0947 \\
Dark & & & $\mathbf{0 . 0 2 3 0}$ & & 0.1977 \\
Day 1 & & & 0.5294 & & 0.5967 \\
Day 3 & & & 0.0966 & & 0.1030 \\
Day 7 & & & & & \\
\hline
\end{tabular}
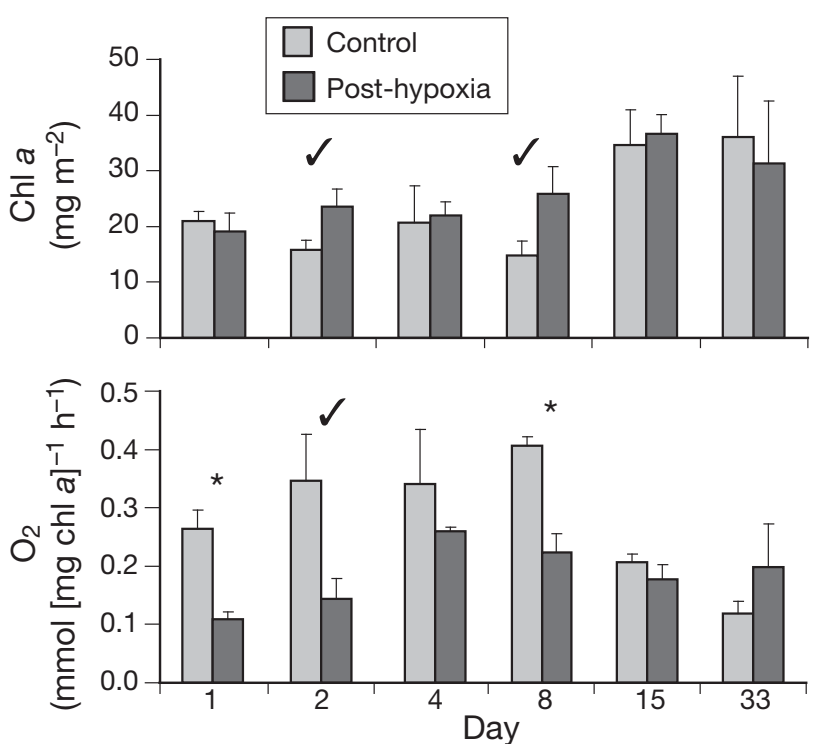

Fig. 6. Mean $(n=3)(a)$ chl a content of the sediment and (b) chl a-normalized primary production after $17 \mathrm{~d}$ hypoxia. Significant post-hypoxic effect (SNK or 1-way ANOVA) at ${ }^{*} \mathrm{p}<0.05$ and $\checkmark \mathrm{p}<0.1$. Error bars: $+\mathrm{SE}$ 


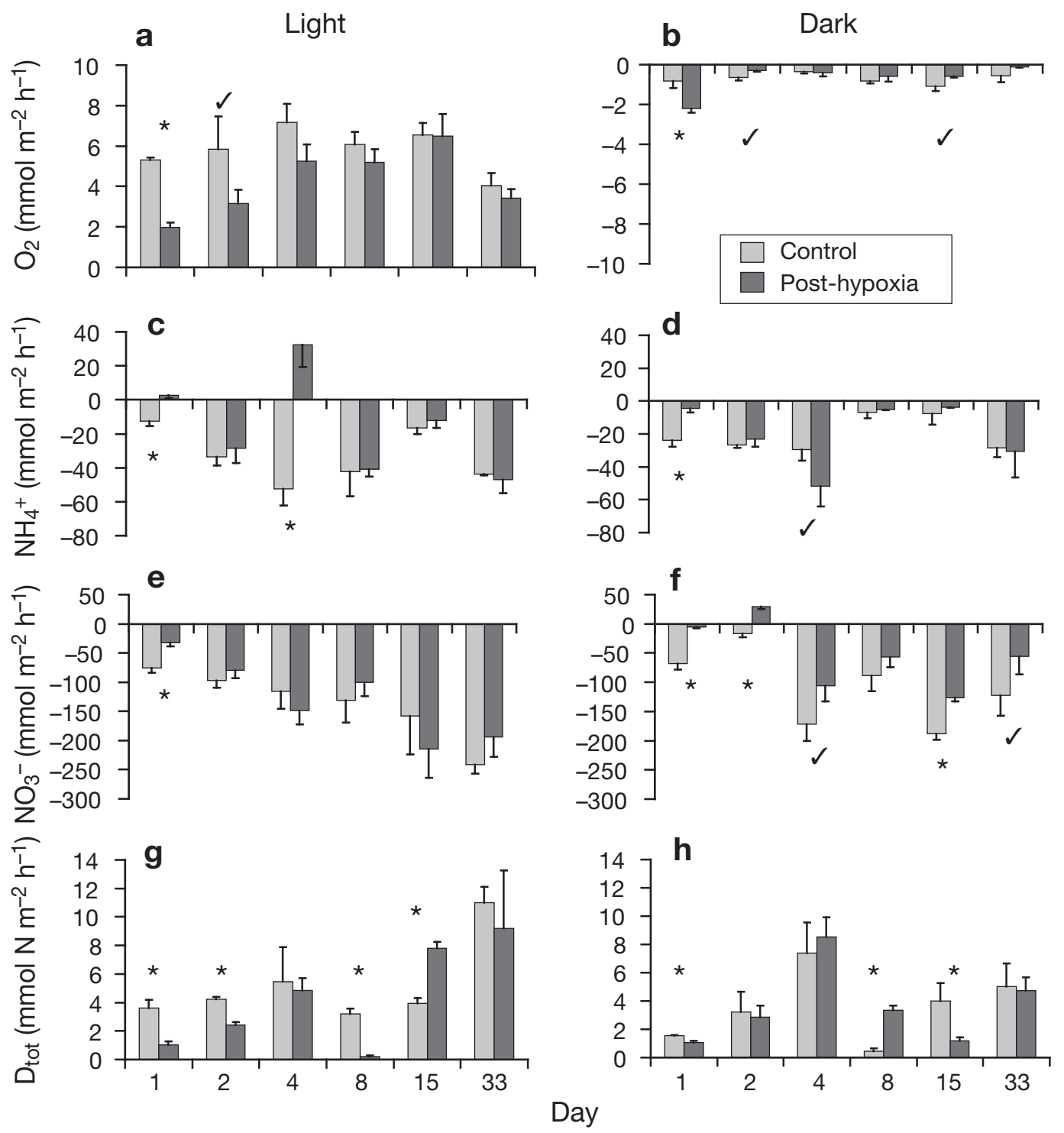

Fig. 7. Mean $(\mathrm{n}=4)$ oxygen and nitrogen fluxes and denitrification in light (daytime) and dark (nighttime) conditions after longterm (17 d) hypoxia. (a,b) Oxygen, $(c, d)$ ammonium, $(e, f)$ nitrate and $(g, h)$ denitrification. Significant post-hypoxic effect $($ SNK or 1 -way ANOVA) at ${ }^{*} \mathrm{p}<0.05$ and $\sqrt{\mathrm{p}}<0.1$. Error bars: SE

\section{DISCUSSION}

\section{Experimental setup}

The aim of the setup was to build a system that, in as many aspects as possible, should allow for extrapolation to field conditions. This was achieved for light (except for ultraviolet radiation that was excluded by the roof), water temperature, salinity and nutrient concentrations. By using unfiltered seawater and letting water exit through an overflow, the sediment remained an open system (Matthiessen \& Hillebrand 2006), allowing immigration and emigration of larvae and spores. By using undisturbed sediment, the nat- ural organism diversity, as well as heterogeneity (patchiness) could be retained. The heterogeneity could, on the other hand, also imply problems of reproducibility. Bartoli et al. (2003) tested the reproducibility of sediment-water core fluxes by using $50 \mathrm{~cm}^{2}$ cores and showed that especially ammonium and silicate flux measurements demand high replication. If the average patch size of MPB $\left(\sim 80 \mathrm{~cm}^{2}\right)$ observed on a tidal flat (Blanchard 1990) also applies to our sediment, then our flux measurements over a core area of $490 \mathrm{~cm}^{2}$ should have decreased at least some of the variability caused by patchiness. Despite these advantages of our experimental setup, there were also some limitations. The water depth in the experiment was 
Table 3. Effect of 17 d hypoxia on the integrated community function analyzed using 2-way permutational multivariate analysis of variance (PERMANOVA) (Anderson 2001) and permutational multivariate dispersion (PERMDISP) with a posteriori pair-wise comparisons of Treatment $(\mathrm{T})$ under each level of Day (D). The variables included in the analysis are oxygen, nutrient fluxes and denitrification (6 variables) analyzed for dark and light conditions, respectively. Significances at $\mathrm{p}<0.05$ are bold, and $\mathrm{p}<0.1$ italic

\begin{tabular}{|c|c|c|c|c|c|c|}
\hline & \multicolumn{3}{|c|}{ PERMANOVA } & \multicolumn{3}{|c|}{ PERMDISP } \\
\hline & Factor & $F$ & $\mathrm{p}$ & Factor & $F$ & $\mathrm{p}$ \\
\hline Light & $\mathrm{D} \times \mathrm{T}$ & 3.3142 & 0.0046 & $\mathrm{~T}$ & 9.0982 & 0.0052 \\
\hline Dark & $\mathrm{T}$ & 8.1553 & 0.0036 & $\mathrm{D} \times \mathrm{T}$ & 30.0269 & 0.0001 \\
\hline \multicolumn{7}{|c|}{ a posteriori pair-wise comparisons } \\
\hline \multicolumn{7}{|l|}{ Light } \\
\hline Day 1 & & & 0.0159 & & & 0.0283 \\
\hline Day 2 & & & 0.6277 & & & 0.3083 \\
\hline Day 4 & & & 0.0910 & & & 0.0868 \\
\hline Day 8 & & & 0.8131 & & & 0.3908 \\
\hline Day 15 & & & 0.0829 & & & 0.5713 \\
\hline Day 33 & & & 0.2009 & & & 0.2559 \\
\hline \multicolumn{7}{|l|}{ Dark } \\
\hline Day 1 & & & 0.0006 & & & 0.0567 \\
\hline Day 2 & & & 0.0992 & & & 0.2717 \\
\hline Day 4 & & & 0.2291 & & & 0.8285 \\
\hline Day 8 & & & 0.5231 & & & 0.0274 \\
\hline Day 15 & & & 0.0960 & & & 0.0288 \\
\hline Day 33 & & & 0.8264 & & & 0.0280 \\
\hline
\end{tabular}

only $\sim 10 \mathrm{~cm}$, while the depth at the collection site was $\sim 1.5 \mathrm{~m}$. Moreover, night incubations were started shortly after the onset of darkness, which could have resulted in somewhat overestimated rates of $\mathrm{CR}$, since the respiration of fauna is often highest at the onset of darkness, gradually diminishing to less than half just before dawn (Wenzhöfer \& Glud 2004). However, despite these limitations, our results should be of acceptable ecological relevance at least for the sediment type we used. Furthermore, the sediment type, silt, is also the one most often subjected to hypoxia due to its occurrence in areas with more stagnant conditions.

\section{Sensitivity and recovery of the sediment system}

In both experiments the sediment system was dominated by autotrophic organisms. Moreover, nutrient fluxes were directed into the sediment, indicating a high algal nutrient demand and, hence, probably nutrient limitation. However, in some aspects the 2 experiments differed. Besides the duration of the hypoxic treatment ( 2 vs. $17 \mathrm{~d}$ ) and the experiment itself ( 7 vs. 33 d), the temperature regime was different. The short-term experiment was carried out in late June and first week of July $\left(20\right.$ to $25^{\circ} \mathrm{C}$ ), while the long-term experiment was run from late August until end of
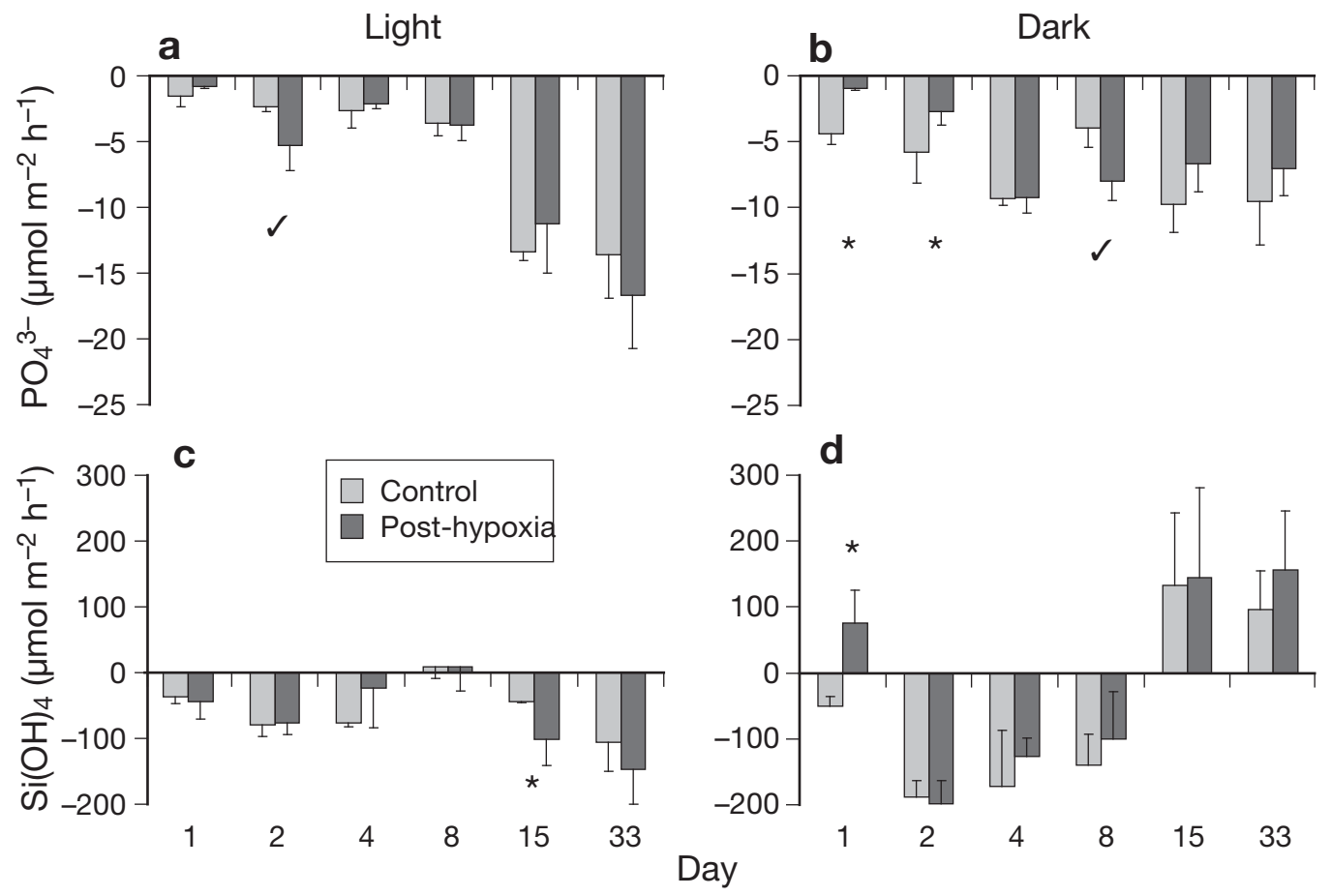

Fig. 8. Mean $(\mathrm{n}=4)$ phosphate and silicate fluxes in light (daytime) and dark (nighttime) conditions after long-term (17 d) hypoxia. (a,b) Phosphate and (c,d) silicate. Significant post-hypoxic effect (SNK or 1-way ANOVA) at ${ }^{*} \mathrm{p}<0.05$ and $\checkmark \mathrm{p}<0.1$. 


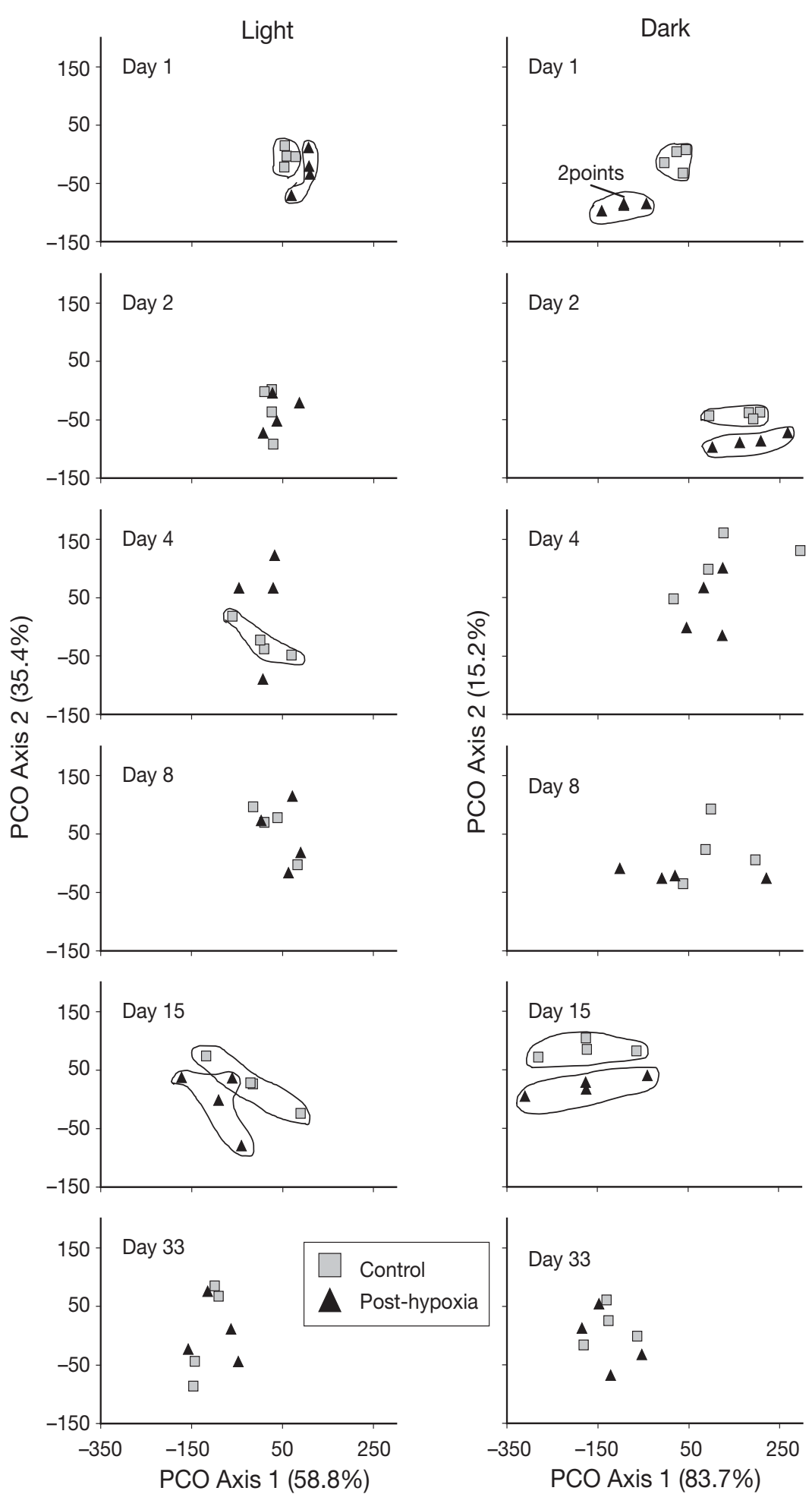

Fig. 9. Principal coordinate plot (PCO) of the treatments (control and posthypoxia) based on the analysis of the functional variables denitrification, oxygen and nutrient fluxes (6 variables). Axes show the percentages of explained variation. A clearer separation is seen under dark compared to light conditions. There is an increased dispersion within the group of posthypoxic cylinders. A pattern of mixing and separation is seen, indicating an oscillating response towards the point of recovery. Significant groupings are encircled
October $\left(8\right.$ to $\left.18^{\circ} \mathrm{C}\right)$. Still, the main effects of hypoxia observed were the same.

After an initial algal response to hypoxia evident as decreased algal production (but not biomass), variables related to algal activity recovered faster than heterotrophic processes, such as denitrification. This finding supports our hypothesis that primary production is less sensitive than heterotrophic functions, probably due to a high resistance and redundancy of the benthic diatom community. The recovery of affected single variables, as well as of the integrated sediment function, was generally faster in light. Moreover, hypoxia effects on nutrient fluxes tended to be clearer in the dark. These 2 findings further emphasize the importance of microalgae in the recovery of the sediment system. It is highly interesting to note that the recovery of the basic system functions studied occurred without a concomitant recovery of the macro- and meiofauna communities that were severely diminished by the hypoxia. Our hypothesis that recovery time is related to the duration of the disturbance was also supported by our results.

In the following, we will first discuss the effects observed on individual variables immediately (Day 1) after the hypoxic treatment ended (sensitivity), and after that we will consider the subsequent recovery during the rest of the experiment (resilience). After this, we will discuss the integrated functional response and recovery as analysed by multivariate methods.

Sensitivity of the microbenthic community - individual variables

In the short-term experiment $(2 \mathrm{~d}$ hypoxia), there were no visual changes to the sediment surface; neither did the chl $a$ content change during, or shortly after, the hypoxic treatment. However, the function of the algal community was negatively affected, a fact that was reflected in lower oxygen production as well as chl a-normalized production on Day 1. In the long-term hypoxia experiment (17 d hypoxia) the changed colour of the sediment surface, from brownish-yellow to grey, after the first few days of the hypoxia exposure indicated that the MPB had moved away from 
the surface, since they are motile and respond to conditions in their local environment. Except for the effect of lower oxygen level limiting the respiration, there is also a possibility of a degree of carbon deficiency under the hypoxic treatment. This interpretation is supported by the fact that, while primary production and chl a-normalized production decreased on Day 1 , there was no change in the chl a content of the top $3 \mathrm{~mm}$ of the sediment. Thus, although the algae were physiologically affected during the hypoxia, they did survive. The algae might have gone into a dormant state after migrating down below the sediment surface and thereby kept respiration demands to a minimum. The reason for moving down could simply be that the hypoxia exposure was from above through the overlying water and also to stay out of the light when not able to uphold a positive production compared to respiration. The high porosity of the sediment in the experiment most likely resulted in a slower surface re-oxygenation when the surface water became oxic compared to what would have been the case in a more sandy sediment.

The uptake of nutrients was initially affected by hypoxia in both experiments. The lower uptake of ammonium, phosphate and silicate on Day 1 was probably and primarily related to the decreased activity of MPB. Decreased nitrification, and hence decreased nitrification-coupled denitrification, caused by poor oxygen conditions of the sediment surface layer (Trimmer et al. 2000, Astill \& Lavery 2001), may have also contributed to a lower ammonium uptake. The small release of ammonium in the long-term experiment on Days 1 and 4 may partly reflect enhanced degradation of accumulated dead material, indicated by higher CR in the dark in the post-hypoxic cylinders. Dissimilative nitrate reduction to ammonium (DNRA) may also increase along with high sulphide concentrations and increasing ammonium release (An \& Gardner 2002). Lower nitrate uptake observed in the dark in both experiments may not be directly connected to lower algal activity, since uptake of nitrate in the dark is generally low due to the high energy cost of nitrate reduction (Ullrich et al. 1998, Riegman et al. 2000). Decreased denitrification, as shown in the long-term experiment, can be one reason for this lower dark uptake of nitrate in the dark. Significantly decreased phosphate uptake on Day 1 may also be caused by lower oxygenation of the sediment, hindering phosphate adsorption to iron hydroxides in the sediment (Gomez et al. 1999, Heijs et al. 2000).

Higher CR in the post-hypoxic cylinders in both experiments indicated degradation of dead material, most probably in the form of infauna (and meiofauna), which were observed on the sediment surface during the hypoxia. Silicate is usually released through ventilation of the sediment by burrowing macrofauna (e.g.
Marinelli 1992, 1994). In addition to decreased algal uptake of silica, increased activity in the sediment by the few remaining bioturbators (Nereids and bivalves) may have contributed to the silica release in the longterm experiment.

\section{Resilience of the microbenthic community-} individual variables

In accordance with our second hypothesis, we found a relationship between the duration of the hypoxic event and the time needed for recovery, as has also been generally suggested for benthic communities by Boesch \& Rosenberg (1981). After a 2 d hypoxia the system recovered in most variables within $1 \mathrm{wk}$, and following a $17 \mathrm{~d}$ hypoxia the system recovered within 1 mo. However, considering the oscillating pattern of the recovery process, a definite conclusion that a final recovery occurred may be difficult to draw.

After the short-term hypoxia, the MPB primary production recovered rapidly, with no significant differences between the post-hypoxic cylinders and the controls remaining after Day 1 . Among other variables, $3\left(\mathrm{CR}, \mathrm{NH}_{4}{ }^{+}\right.$and $\mathrm{PO}_{4}{ }^{-}$flux) out of 12 (including light and dark) showed a significant difference at the final sampling (Table 1). The higher ammonium uptake in darkness on Day 7 also indicated increased algal and bacterial activity. The fact that the CR in the posthypoxic treatment was lower on Day 7 suggests that the main bacterial degradation of the dead organisms seen in the beginning of the experiment was over. Lower densities of respiring fauna may also have contributed to the lower CR. On Day 7, uptake of phosphate in light was still lower, which may indicate that the oxygen gradient of the sediment was not fully restored. The higher uptake of silicate in the posthypoxic sediment in the light on Day 3 was due to the increased activity of the MPB. The release of silicate in the dark on the same day may be explained by the increased activity of the remaining infauna.

After the long-term hypoxia the primary production of MPB, as in the case of the short-term hypoxia, showed a rapid recovery. The lower chl a-normalized production (when compared with controls) on Days 2 and 8 could be explained by lower total activity of the MPB in combination with the higher chl a content of the sediment found on these days. This increase of chl $a$ was most likely an indirect, top-down effect of hypoxia related to decreased grazing pressure, since a large part of the grazing fauna probably died during the $17 \mathrm{~d}$ hypoxic event. The fact that the CR turned out to be lower after Day 1 may imply that the major degradation of excess dead material was over and that the faunal abundance was low. The release of ammo- 
nium until Day 4 in light was due to the proceeding degradation of the dead fauna and probably still decreased nitrification-coupled denitrification. The release of nitrate on Day 2 in the dark can be connected in part to lower denitrification in the posthypoxic cylinders. However, the denitrification rates were around 1 magnitude lower than the flows of nitrate and thereby of limited explanatory value. Increased uptake of phosphate in the dark on Day 8 indicates improved oxygenation of the sediment leading to iron-hydroxide adsorption.

Integrated functional response and recovery

Both the multivariate location and dispersion were analyzed by using permutational methods that are insensitive to non-normality in multivariate datasets. The variables included in the analyses were fluxes of oxygen and nutrients $\left(\mathrm{NH}_{4}{ }^{+}, \mathrm{NO}_{3}{ }^{-}, \mathrm{PO}_{4}{ }^{3-}, \mathrm{Si}(\mathrm{OH})_{4}\right)$ as well as denitrification both in light and dark. Since the included variables were of chemical nature with both positive and negative fluxes, the analysis was based on Euclidean distance that includes double zeros. Including double zeros means that 2 replicates with a value of 0 in the same variable are counted as more similar, which is not the case with coefficients such as BrayCurtis, which excludes double zeros. In the dispersion analysis the distances between the replicates and the treatment-group centroid $(z)$ are compared between the groups, while in the location analysis the withintreatment-group distances are compared with the between-group distances. Both analyses use, as do univariate analyses of variance, the sum of squares.

The multivariate analysis of the integrated function showed that the 2 treatments were initially clearly separated both in the light and dark in both experiments. In the long-term experiment, however, the separation in the dark was clearer than in the light (Fig. 9). After the initial effect the timing of the separation was partly different in light and dark in both experiments.

In the short-term experiment the dispersion within the treatment groups was lower for the post-hypoxic cylinders than the controls (Fig. 5, Table 2), while after the long-term hypoxia there was an increase in dispersion within the treatment groups, especially for the post-hypoxic cylinders. Chapman et al. (1995) have suggested that environmental stress may decrease the variability in the structure of ecological assemblages, while Warwick \& Clarke (1993) suggested the opposite, i.e. that environmental stress in fact increases variability. In the long-term experiment the analysis also showed that the groups mixed and then separated during the time of the experiment. This indicates that the recovery process oscillates towards a point of re- covery instead of showing a linear return. A similar pattern was seen in another experiment studying recovery of a sediment system after an exposure to a toxicant under different nutrient status (Larson et al. 2007, Sundbäck et al. 2007).

It is interesting to note that both the suggestions by Chapman et al. (1995) (stress decreases dispersion) and Warwick \& Clarke (1993) (stress increases dispersion) might be applicable to the present study. However, their studies dealt with structural variability, and the variability studied in the present study is based on the systems function; except for the basal function of variability no direct comparisons can be made. An interesting question that arises is the possiblity that the duration and severity of the perturbation will decide whether there will be decreased or increased variability. That is, May short and not too severe perturbations tend to decrease variability, while longer and more severe perturbations result in an increased variability?

\section{Sensitivity of organism groups}

From an ecosystem point of view, the limitation of the present study was that we only measured variables related to MPB and bacterial activity and did not consider the function of microfauna, meiofauna or macrofauna. Based on the few variables we measured, we conclude that at least part of the bacterial component was more sensitive, directly or indirectly, to hypoxia than MPB. Particularly, bacteria that are involved in the denitrification appear sensitive. This also agrees with our recovery experiments after toxicant exposure (Larson et al. 2007, Sundbäck et al. 2007). Also the infauna, e.g. Corophium spp., known to enhance sediment nitrate uptake and denitrification through effective burrow irrigation (Pelegri et al. 1994, Rysgaard et al. 1995), had died during hypoxia as did most of the other macrofauna. Although we do not have any quantitative information on the response and recovery of meiofauna, we have some indirect indications that the meiofauna was affected by the hypoxia; one apparent effect was increased chl a content in the hypoxiatreated sediment, probably reflecting decreased grazing on MPB (cf. Carman et al. 1997). Studies on meiobenthic recovery after short-term hypoxia (3d, closed incubations decreasing $\mathrm{O}_{2}$ saturation to $\sim 2.5 \%$ ) showed a recovery within 1 mo (Guerrini et al. 1998). Macrobenthic communities in shallow areas show full recovery within $1.5 \mathrm{yr}$, with recolonisation dominated by larval settlement ( $\mathrm{Lu} \& \mathrm{Wu} 2000$ ). These studies on meio- and macrobenthos recovery also included horizontal migration since they were field studies. The fast recovery of the functions of microbenthos seen in the present study may have been aided by the immigration 
of bacteria through the incoming water, but import of benthic diatoms may have been slower even though they can remain in suspension for a while. This should mean that the main recovery was driven by the organisms already present in the sediment, and this further highlights the role for resilience of the benthic diatom community associated to sediments. That the MPB truly is capable of surviving adverse conditions has been shown before (Admiraal 1984, Forster \& MartinJezequel 2005) and was not an aim of the present study, which instead aimed for the role of resilience of microbenthic functions.

Turner et al. (1993) have, through modeling, studied how temporal and spatial scale ratios influence the stability of a system. If the area exposed to disturbance is small relative to the total area of the system, then the system will remain stable even if the disturbance interval is shorter than the recovery time. The long-term stability of a system is threatened only when the disturbance interval is much shorter than the time of recovery (high temporal ratio) in combination with a large proportion of the system affected by the disturbance (high spatial ratio). This instability will increase the risk of irreversible shifts in system function (Turner et al. 1993). Since hypoxia in the field often occurs as repeated events of different durations and the proportion of habitat areas affected varies, future studies should consider the resilience of microbenthic communities that are exposed to repeated perturbations on different spatial scales. Norkko et al. (2006) showed in a case study a strong correlation between scale and recovery after anoxia on patches of different size. The correlation was strongest when recolonisation was driven by horizontal migration such as the lugworm Arenicola. More opportunistic organisms such as Corophium quickly took advantage of the free space, and the larger the post-anoxic area, the more positive was the effect on Corophium abundance. Also, the MPB was positively affected by the slow recolonisation of the surface deposit-feeding Arenicola (Norkko et al. 2006).

The prediction by DeAngelis et al. (1989), that resilience is higher when nutrient turnover is high and food chains are short, is applicable for the comparison of the recovery of micro-, meio- and macrobenthic communities. Resilience decreases when going from the microbenthic community with high nutrient turnover up to the macrobenthic communities with lower nutrient turnover rates. Furthermore, the resilience of the microbenthic community is enhanced by the resistance of its main primary producing component, the diatoms. Also, the short distance of energy transfer and very rapid turnover within the microbial mat and uppermost part of the sediment most likely contribute to the apparent high resilience.

\section{CONCLUSIONS}

The microbenthic communities show a high resilience after single hypoxic events, and the time for recovery is related to the duration of hypoxia. The high resilience of shallow-water microbenthic communities is largely related to the resistance of diatoms that will facilitate recolonisation of the microbenthic community and, further, the meio- and macrobenthic communities. The recovery of the basic functions studied was obviously more or less independent of fauna since no concomitant recovery of adult fauna community occurred. Through a rapid restoration of the oxygen gradient of the sediment surface and by production of food for colonising grazers and deposit-feeders, the lower trophic levels of the system will be fully functional within weeks after hypoxic events in shallowwater areas with silty-sandy sediment. The present study only tried to assess the resilience after single events of hypoxia. Repeated events of hypoxia are likely to lower the resilience of the system and eventually increase the risk of irreversible shifts in composition and function of the system, especially if the period between perturbations is shorter than the recovery time after single events.

The fact that we found a decreased variability after short-term hypoxia, while we found an increased variability after the long-term hypoxia, might be coincidental but is still intriguing. The relationship between level of stress and direction of response in functional variability asks for some attention.

Acknowledgements. Funding was received from the Swedish Environmental Protection Agency, Swedish Research Council for Environment, Agricultural Sciences and Special Planning (FORMAS), the Marine Research Centre of of the University of Gothenburg (GMF), the Memorial Fund of Birgit and Birger Wåhlström and the Captain Stenholm Fund. We are grateful to T. Olsson for assisting during sampling and experimental work. We thank the crew of RV 'Oscar von Sydow' for help with the sediment collection. We also thank C. Gren and G. Gunnarsson (technicians, KMRS) for help in the workshop.

\section{LITERATURE CITED}

Admiraal W (1984) The ecology of estuarine sediment-inhabiting diatoms. In: Round FE, Chapman DJ (eds) Progress in phycological research, Vol 3. Biopress, Bristol, p 269-322

An SM, Gardner WS (2002) Dissimilatory nitrate reduction to ammonium (DNRA) as a nitrogen link versus denitrification as a sink in a shallow estuary (Laguna Madre/Baffin Bay, Texas). Mar Ecol Prog Ser 237:41-50

Anderson MJ (2001) A new method for non-parametric multivariate analysis of variance. Austral Ecol 26:32-46

Astill H, Lavery PS (2001) The dynamics of unattached benthic macroalgal accumulations in the Swan-Canning Estuary. Hydrol Process 15:2387-2399

Austen MC, Lambshead PJD, Hutchings PA, Boucher G and 
others (2002) Biodiversity links above and below the marine sediment-water interface that may influence community stability. Biodivers Conserv 11:113-136

Bartoli M, Nizzoli D, Viaroli P (2003) Microphytobenthos activity and fluxes at the sediment-water interface: interactions and spatial variability. Aquat Ecol 37:341-349

Blanchard G (1990) Overlapping microscale dispersion patterns of meiofauna and microphytobenthos. Mar Ecol Prog Ser 68:101-111

Boesch DF, Rosenberg R (1981) Response to stress in marine benthic communities. In: Barrett GW, Rosenberg R (eds) Stress effects on natural ecosystems. John Wiley, Chichester, p 179-200

Carman KR, Fleeger JW, Pomarico SM (1997) Response of a benthic food web to hydrocarbon contamination. Limnol Oceanogr 42:561-571

Carpenter SR, Kraft CE, Wright R, Xi H, Soranno PA, Hodgson JR (1992) Resilience and resistance of a lake phosphorus cycle before and after food web manipulation. Am Nat 140:781-798

Chapman MG, Underwood AJ, Skilleter GA (1995) Variability at different spatial scales between a subtidal assemblage exposed to the discharge of sewage and two control locations. J Exp Mar Biol Ecol 189:103-122

Dalsgaard T, Nielsen LP, Brotas V, Viaroli P and others (2000) Protocol handbook for NICE-Nitrogen Cycling in Estuaries. Ministry of Environment and Energy, National Environmental Research Institute, Department of Lake and Estuarine Ecology, Denmark

$>$ DeAngelis DL (1980) Energy flow, nutrient cycling and ecosystem resilience. Ecology 61:764-771

$>$ DeAngelis DL, Mulholland PJ, Palumbo AV, Steinman AD, Huston MA, Elwood JW (1989) Nutrient dynamics and food web stability. Annu Rev Ecol Syst 20:71-95

Diaz RJ, Rosenberg R (1995) Marine benthic hypoxia: a review of its ecological effects and the behavioural responses of benthic macrofauna. Oceanogr Mar Biol Annu Rev 33:245-303

Forster RM, Martin-Jezequel VR (2005) Photophysiological variability of microphytobenthic diatoms after growth in different types of culture conditions. Phycologia 44: 393-402

> Gomez E, Durillon C, Rofes G, Picot B (1999) Phosphate adsorption and release from sediments of brackish lagoons: $\mathrm{pH}, \mathrm{O}_{2}$ and loading influence. Water Res 33:2437-2447

> Grimm V, Wissel C (1997) Babel, or the ecological stability discussions: an inventory and analysis of terminology and a guide for avoiding confusion. Oecologia 109:323-334

Guerrini A, Colangelo MA, Ceccherelli VU (1998) Recolonisation patterns of meiobenthic communities in brackish vegetated and unvegetated habitats after induced hypoxia/ anoxia. Hydrobiol 375-376:73-87

Heijs SK, Azzoni R, Giordani G, Jonkers HM, Nizzoli D, Viaroli P, van Gemerden H (2000) Sulfide-induced release of phosphate from sediments of coastal lagoons and the possible relation to the disappearance of Ruppia sp. Aquat Microb Ecol 23:85-95

Howarth RW, Billen G, Swaney D, Townsend A and others (1996) Regional nitrogen budgets of riverine $\mathrm{N}$ and $\mathrm{P}$ fluxes for the drainage of to the North Atlantic Ocean: natural and human influences. Biogeochemistry 35:75-139

Karim MR, Sekine M, Ukita M (2002) Simulation of eutrophication and associated occurrence of hypoxic and anoxic condition in a coastal bay in Japan. Mar Pollut Bull 45: 280-285

Larson F, Petersen DG, Dahllöf I, Sundbäck K (2007) Combined effects of an antifouling biocide and nutrient status on a shallow-water microbenthic community. Aquat Microb Ecol 48:277-294

Lomstein BA, Jensen AGU, Hansen JW, Andreasen JB, Hansen LS, Berntsen J, Kunzendorf H (1998) Budgets of sediment nitrogen and carbon cycling in the shallow water of Knebel Vig, Denmark. Aquat Microb Ecol 14:69-80

Lorenzen CJ (1967) Determination of chlorophyll and pheopigments: spectrophotometric equations. Limnol Oceanogr 12:343-346

Lu L, Wu RSS (2000) An experimental study on recolonisation and succession of marine macrobenthos in defaunated sediment. Mar Biol 136:291-302

Marinelli RL (1992) Effects of polychaetes on silicate dynamics and fluxes in sediments-importance of species, animal activity and polychaete effects on benthic diatoms. J Mar Res 50:745-779

Marinelli RL (1994) Effects of burrow ventilation on activities of a terebellid polychaete and silicate removal from sediment pore waters. Limnol Oceanogr 39:303-317

- Matthiessen B, Hillebrand H (2006) Dispersal frequency affects local biomass production by controlling local diversity. Ecol Lett 9:652-662

McArdle BH, Anderson MJ (2001) Fitting multivariate models to community data: a comment on distance based redundancy analysis. Ecology 82:290-297

McGlathery KJ, Anderson IC, Tyler AC (2001) Magnitude and variability of benthic and pelagic metabolism in a temperate coastal lagoon. Mar Ecol Prog Ser 216:1-15

Nielsen LP (1992) Denitrification in sediment determined from nitrogen isotope pairing. FEMS Microbiol Ecol 86: 357-362

Nielsen SL, Banta GT, Pedersen MF (2004) Estuarine nutrient cycling: the influence of primary producers. The fate of nutrients and biomass. Kluwer Academic, Dordrecht

Nixon SW (1995) Coastal marine eutrophication: a definition, social causes and future concerns. Ophelia 41:199-219

Norkko A, Rosenberg R, Thrush SF, Whitlatch RB (2006) Scale- and intensity-dependent disturbance determines the magnitude of opportunistic response. J Exp Mar Biol Ecol 330:195-207

Paerl HW, Pinckney JL (1996) A mini-review of microbial consortia: their roles in aquatic production and biogeochemical cycling. Microb Ecol 31:225-247

Pelegri SP, Nielsen LP, Blackburn TH (1994) Denitrification in estuarine sediment stimulated by the irrigation activity of the amphipod Corophium volutator. Mar Ecol Prog Ser 105:285-290

Pihl L, Rosenberg R (1982) Production, abundance and biomass of mobile epibenthic marine fauna in shallow water, western Sweden. J Exp Mar Biol Ecol 57:273-301

Pihl L, Svenson A, Moksnes PO, Wennhage H (1999) Distribution of green algal mats throughout shallow soft bottoms of the Swedish Skagerrak archipelago in relation to nutrient sources and wave exposure. J Sea Res 41:281-294

Riegman R, Stolte W, Noordeloos AAM, Slezak D (2000) Nutrient uptake and alkaline phosphate (EC 3:1:3:1) activity of Emiliania huxleyi (Prymnesiophyceae) during growth under $\mathrm{N}$ and $\mathrm{P}$ limitation in continuous cultures. J Phycol 36:87-96

Risgaard-Petersen N (2003) Coupled nitrification-denitrification in autotrophic and heterotrophic estuarine sediments: on the influence of benthic microalgae. Limnol Oceanogr 48:93-105

Rosenberg R, Elmgren R, Fleischer S, Jonsson P, Persson G, Dahlin H (1990) Marine eutrophication case studies in Sweden. Ambio 19:102-108

Rysgaard S, Christensen PB, Nielsen LP (1995) Seasonal vari- 
ation in nitrification and denitrification in estuarine sediment colonized by benthic microalgae and bioturbating infauna. Mar Ecol Prog Ser 126:111-121

Strickland JD, Parsons TR (1972) A practical handbook of seawater analysis. Bull Fish Res Board Can 167

Sundbäck K, Graneli W (1988) Influence of microphytobenthos on the nutrient flux between sediment and water: a laboratory study. Mar Ecol Prog Ser 43:63-69

Sundbäck K, McGlathery KJ (2005) Interactions between benthic macroalgal and microalgal mats. In: Kristensen E, Kostka JE, Haese RH (eds) Interactions between macroand microorganisms in marine sediments. AGU, Washington, $\mathrm{p}$ 7-29

Sundbäck K, Jönsson B, Nilsson P, Lindström I (1990) Impact of accumulating drifting macroalgae on a shallow-water sediment system: an experimental study. Mar Ecol Prog Ser 58:261-274

Sundbäck K, Petersen DG, Dahllöf I, Larson F (2007) Combined nutrient-toxicant effects on a shallow-water marine sediment system: sensitivity and resilience of ecosystem functions. Mar Ecol Prog Ser 330:13-30

Trimmer M, Nedwell DB, Sivyer DB, Malcolm SJ (2000) Seasonal organic mineralisation and denitrification in intertidal sediments and their relationship to the abundance of Enteromorpha sp. and Ulva sp. Mar Ecol Prog Ser 203: $67-80$

Initial editorial responsibility: Howard Browman, Storebø, Norway (until November 5, 2007); Final editorial responsibility: Hans Heinrich Janssen, Oldendorf/Luhe, Germany
Turner MG, Romme WH, Gardner RH, Oneill RV, Kratz TK (1993) A revised concept of landscape equilibriumdisturbance and stability on scaled landscapes. Landscape Ecol 8:213-227

Ullrich WR, Lazarova J, Ullrich CI, Witt FG, Aparicio PJ (1998) Nitrate uptake and extracellular alkalinization by the green alga Hydrodictyon reticulatum in blue and red light. J Exp Bot 49:1157-1162

Underwood AJ (1989) The analysis of stress in natural populations. Biol J Linn Soc 37:51-78

Underwood GJC, Kromkamp J (1999) Primary production by phytoplankton and microphytobenthos in estuaries. Adv Ecol Res 29:93-153

Viaroli P, Bartoli M, Bondavalli C, Christian RR, Giordani G, Naldi M (1996) Macrophyte communities and their impact on benthic fluxes of oxygen, sulphide and nutrients in shallow eutrophic environments. Hydrobiol 329:105-119

- Warwick RM, Clarke KR (1993) Increased variability as a symptom of stress in marine communities. J Exp Mar Biol Ecol 172:215-226

Wenzhöfer F, Glud RN (2004) Small-scale spatial and temporal variability in coastal benthic $\mathrm{O}_{2}$ dynamics: effects of fauna activity. Limnol Oceanogr 49:1471-1481

Wetzel MA, Weber A, Giere O (2002) Recolonisation of anoxic/ sulfidic sediments by marine nematodes after experimental removal of macroalgal cover. Mar Biol 141:679-689

Submitted: February 6, 2007; Accepted: January 14, 2008

Proofs received from author(s): February 29, 2008 